\title{
Corn Production for Silage Subjected to Potassium Fertilization and Water Depths
}

\author{
Edvaldo Eloy Dantas Junior ${ }^{1}$, Lucia Helena Garófalo Chaves ${ }^{1}{ }^{*}$, Josely Dantas Fernandes ${ }^{2}$ \\ ${ }^{1}$ Federal University of Campina Grande, Campina Grande, Brazil \\ ${ }^{2}$ State University of Paraíba, Campina Grande, Brazil \\ Email: "Ihgarofalo@hotmail.com,joselysolo@yahoo.com.br
}

Received 15 February 2016; accepted 27 March 2016; published 30 March 2016

Copyright (C) 2016 by authors and Scientific Research Publishing Inc.

This work is licensed under the Creative Commons Attribution International License (CC BY).

http://creativecommons.org/licenses/by/4.0/

(c) ()) Open Access

\section{Abstract}

This study was carried out with the objective of evaluating the effect of water depths and potassium fertilizer levels on corn yield for silage. The experimental design was a randomized block design in a split-plot with six water depths based on crop potential evapotranspiration (ET cp $_{\text {) in }}$ levels: $0.25 ; 0.50 ; 0.75 ; 1.00 ; 1.25$ and $1.50 \mathrm{ET}_{\mathrm{cp}}$, and six amounts of potassium, 0, 20, 40, 60, 80 and $100 \mathrm{~kg} \cdot \mathrm{ha}^{-1}$, in four replicates. The irrigation system was dripped. Before sowing was applied to the soil to nitrogen $(\mathrm{N})$ and phosphate $(\mathrm{P})$ fertilizers, corn was sown ten days after the fertilization using seeds from hybrid AG 1051. Manual harvesting of ears occurred 67 days after sowing. Production variables observed were fresh matter of plant with (FPMwiths) and without (FPMwithouts) the ears. The fresh matter of plant with and without the ears was influenced significantly by factors analyzed, the $1 \%$ level of probability by $F$ test. The water depths in irrigation that maximized the physiological parameters of plants as FPMwiths and FPMwithouts were, respectively, $690 \mathrm{~mm}$ and $766.7 \mathrm{~mm}$. The quantitative potassium to maximize physiological parameters of FMP with ears and FMP without ears was, respectively, $104.75 \mathrm{~kg} \mathrm{ha}^{-1}$ and $52.1 \mathrm{~kg} \mathrm{ha}^{-1}$.

\section{Keywords}

Zea mays L., Irrigation, Silage, Plants

\section{Introduction}

Livestock has constituted one of the main economic activities and plays an important role in the agricultural system of the Brazilian semiarid region. However, a major problem for the success of this activity is the production and quality of forage for the herds, which presents as determinant factors water deficiency in soil, asso-

${ }^{*}$ Corresponding author.

How to cite this paper: Dantas Junior, E.E., Chaves, L.H.G. and Fernandes, J.D. (2016) Corn Production for Silage Subjected to Potassium Fertilization and Water Depths. American Journal of Plant Sciences, 7, 671-676.

http://dx.doi.org/10.4236/ajps.2016.74059 
ciated to high temperatures and strong evapotranspiration, which reduces the nutritional value of this food [1].

The silage is an important agricultural technique for maintaining and increasing the productivity of herds, especially during the off-season, when there is scarcity of food for ruminants. Among the various forages, annual and/or perennial plants, maize (Zea mays L.) is one of the most used in ruminant nutrition by presenting a good yield of green matter, excellent quality fermentation and maintaining nutritional value of silage, low operating cost of production, and is grown in various soil and climatic conditions [2]. Silage corn is capable of providing $50 \%$ - 100\% more digestible energy per hectare than any forage. According [2] the corn cultivars evaluated conferred higher nutritional value to silage when compared with sorghum cultivars.

Some researchers have shown that the production of high quality silage depends on the physical composition of the anatomical structures of the corn plant must with around $60 \%-65 \%$ of ears, which determines the share around $45 \%$ of grains in the ensiled material. However, other researchers note that the increase in dry matter production without concomitant increased participation spike in total mass can reduce silage quality. However, not always the greatest proportion of grain in the forage gives better quality silage. The quality of grain and green fraction of the plant (stem, leaf, and straw), combined with the percentage of each of these parts in the plant, determines the nutritional value of the silage [3].

In maize crop, water availability, especially in regions where the rainfall distribution is irregular, becomes a decisive factor in the production and yield [4], in the same way that the nutrients, such as potassium, have high mobility between individual cells, tissues and long-distance transport by xylem and phloem. Potassium can increase the production of dry matter and protein content of the plant due to participation in the activation of enzymes, photosynthesis, translocation of assimilates and nitrogen uptake. However, the deficiency of this nutrient reduces the accumulation of carbohydrates. To avoid this deficiency, the management of potassium fertilizer should be correctly minimizing losses and avoiding the depletion of soil $\mathrm{K}$ [5]. According to [6], the potassium fertilizer on corn planting increased the production of dry biomass of shoots, but did not influence the productivity.

For adequate silage production in the semiarid region, this paper aimed to evaluate the yield of silage corn of the whole plant, subjected to doses of potassium and different amounts of water through irrigation.

\section{Material and Methods}

The experiment was carried out in Sumé, Paraíba State, Brazil (36 52'48"W, 0740'17"S; 532 m asl) during the period, from January to March 2012, in soil classifield as Litholic Neosol. The climate of the region is dry characterized by insufficient rainfall (monthly average in January, February and March 2012: 40.4 mm, 85.5 mm and $144.8 \mathrm{~mm}$, respectively; however in this year there was no precipitation event) and high temperatures; the average temperature is around $24^{\circ} \mathrm{C}$.

The chemical and physical properties of surface layer $(0-0.20 \mathrm{~m})$ were determined according to [7] presented the following attributes: $\mathrm{pH}\left(\mathrm{H}_{2} \mathrm{O}\right)=7.63 ; \mathrm{Ca}^{2+}=10.06 \mathrm{cmol}_{\mathrm{C}} \cdot \mathrm{kg}^{-1} ; \mathrm{Mg}^{2+}=7.56 \mathrm{cmol}_{\mathrm{C}} \cdot \mathrm{kg}^{-1} ; \mathrm{Na}^{2}=0.07$ $\mathrm{cmol}_{\mathrm{c}} \cdot \mathrm{kg}^{-1} ; \mathrm{K}^{+}=0.25 \mathrm{cmol}_{\mathrm{c}} \cdot \mathrm{kg}^{-1}$; organic matter $=13.4 \mathrm{~g} \cdot \mathrm{kg}^{-1} ; \mathrm{P}=54 \mathrm{mg} \cdot \mathrm{kg}^{-1} ; 641.5 \mathrm{~g} \cdot \mathrm{kg}^{-1} \mathrm{clay}, 271.0 \mathrm{~g} \cdot \mathrm{kg}^{-1}$ silt and $87.5 \mathrm{~g} \cdot \mathrm{kg}^{-1}$ sand.

The experimental design was a randomized block design in a split-plot design with six water depths (0.25 $\mathrm{ET}_{\mathrm{cp}} ; 0.50 \mathrm{ET}_{\mathrm{cp}} ; 0.75 \mathrm{ET}_{\mathrm{cp}} ; 1.00 \mathrm{ET}_{\mathrm{cp}} ; 1.25 \mathrm{ET}_{\mathrm{cp}}$ and $1.50 \mathrm{ET}_{\mathrm{cp}}$ ) (based on crop potential evapotranspiration) and six amounts of potassium $\left(0 ; 20 ; 40 ; 60 ; 80\right.$ and $100 \mathrm{~kg} \mathrm{~K}_{2} \mathrm{O}$ per hectare) in four replications (based on plant fertilizer recommendation), totaling 144 experimental units arranged in an area of $2086.56 \mathrm{~m}^{2}$. Data were analyzed using an analysis of variance split plot design, with treatments assigned. Statistical analysis were done using software [8].

According to the results of the soil chemical properties and fertilization recommendation for irrigated maize, in the foundation were placed $66.67 \mathrm{~kg} \cdot \mathrm{ha}^{-1}$ of urea and $105.26 \mathrm{~kg} \cdot \mathrm{ha}^{-1}$ of super-simple phosphate and more $133.33 \mathrm{~kg} \cdot \mathrm{ha}^{-1}$ of urea of covering. The various doses of potassium followed the criterion of lower $(0,20$, $\left.\mathrm{kg} \cdot \mathrm{ha}^{-1}\right)$ and higher $\left(60,80\right.$ and $\left.100 \mathrm{~kg} \cdot \mathrm{ha}^{-1}\right)$ amounts of fertilizer recommendation $\left(40 \mathrm{~kg} \cdot \mathrm{ha}^{-1}\right)$ considering that this recommendation is designed for areas with very different soil and climatic characteristics of the area of this research. The potassium fertilization was carried out in the foundation, where the product was used potassium sulfate.

The irrigation system used was located with drippers. For estimation of local evaporation (EV) used the tank USWB class A, surrounded by exposed soil (circle with radius of $1.0 \mathrm{~m}$ from the tank). Based on relative hu- 
midity of air, lower than $40 \%$, and the average wind speed, $2.55 \mathrm{~m} \cdot \mathrm{s}^{-1}$, considered moderate, was adopted a coefficient of $0.65 \mathrm{Kt}$ tank which, multiplying with evaporation tank (EV) resulting in potential evapotranspiration value, $\mathrm{mm}^{-\mathrm{day}^{-1}}$ (ET0) [9]. To determine the potential evapotranspiration culture (ETcp), we used a lysimeter percolation of $4.50 \mathrm{~m}^{2}$ and depth of $1.50 \mathrm{~m}$. Dividing the value of potential evapotranspiration culture (ETcp) by reference potential evapotranspiration value (ET0) obtains the value of the crop coefficient (Kc). This factor is important in the calculation of replacement water slides corresponding to $25 \%, 50 \%, 75 \%, 100 \%, 125 \%$ and $150 \%$ of ETcP.

The maize hybrid AG 1051 was mechanically sown on 13/01/2012 by planting in double rows of square arrangement (three double rows in each split plots). In each planting hole were placed 3 seeds and after germination were kept 2 plants per hole to production. The distance between plants was $0.4 \times 0.4 \mathrm{~m}$ and between irrigation lines was $1.4 \mathrm{~m}$ with a population of 71,000 plants $\cdot \mathrm{ha}^{-1}$. Manual harvesting of ears in the green stage occurred 67 days after planting.

Fresh matter of plant along with the ears (FMP with ears) and without the ears (FMP without ears) were observed like production variables. Plants of the two outer rows of the subplots were cut close to the ground to give the fresh matter of plants along with the ears. The fresh matter of plants along with the ears was obtained by weighing in $\mathrm{kg}$.

\section{Results and Discussion}

The fresh matter of plant with corn ears was significantly influenced by factors water depths and potassium fertilization and the interaction between the two factors referred to the $1 \%$ level of probability by $\mathrm{F}$ test (Table 1).

The general average of fresh matter of plant with ears throughout the experiment, whereas a population of approximately 56,000 plants per hectare was $62.4 \mathrm{t} \cdot \mathrm{ha}^{-1}$, i.e., greater than the production of $33.564 \mathrm{t} \cdot \mathrm{ha}^{-1}$ in cultivar AG 5011 found by [10] studied corn silage for cattle feed.

Mean values of the fresh matter of the plant with the ears, depending on water depths and potassium fertilization are shown in Table 2.

The mean of 42.83 and $79.05 \mathrm{t} \cdot \mathrm{ha}^{-1}$ corresponding to $\mathrm{W}_{1} \mathrm{~K}_{0}$ and $\mathrm{W}_{6} \mathrm{~K}_{5}$ treatments, respectively, in a population of 56,000 plants, obtained average yield from 0.765 to $1.41 \mathrm{~kg}$ per plant; these values were similar to those obtained by [11] who obtained individual plant mass was of 0.712 to $0.925 \mathrm{~kg}$.

These combinations of water with potassium are important because potassium, among nutrients, stands out when the agricultural production system passes of extractive intensive to technical agriculture, with the use of irrigation. In the case of maize harvesting to make silage is high extraction and export of nutrients, including

\begin{tabular}{|c|c|c|c|}
\hline \multirow{2}{*}{ Source } & \multirow{2}{*}{ Degree of freedom } & \multicolumn{2}{|c|}{ Mean square } \\
\hline & & With ears & Without ears \\
\hline Water depths (W) & 5 & $1265.81^{* *}$ & $559.32^{* *}$ \\
\hline Error-W & 18 & 10.61 & 20.55 \\
\hline Plots & 23 & & \\
\hline Potassium (K) & 5 & $877.53^{* *}$ & $324.24^{* *}$ \\
\hline Int. $\mathrm{W} \times \mathrm{K}$ & 25 & $143.38^{* * *}$ & $133.03^{* *}$ \\
\hline Error-K & 90 & 4.66 & 7.44 \\
\hline Total & 143 & & \\
\hline CV of plots & & $2.22 \%$ & $18.39 \%$ \\
\hline CV of subplots & & $3.46 \%$ & $15.33 \%$ \\
\hline General mean & & $62.4 \mathrm{t} \cdot \mathrm{ha}^{-1}$ & $49.1 \mathrm{t} \cdot \mathrm{ha}^{-1}$ \\
\hline $\mathrm{N}^{\circ}$ of observation & & 144 & 144 \\
\hline
\end{tabular}

${ }^{*},{ }^{* *}$ Significant at $5 \%$ and $1 \%$ probability, respectively. 
Table 2. Mean values of fresh matter of plant with and without ears, depending on the water depths and potassium fertilization Water slides ETcp (mm).

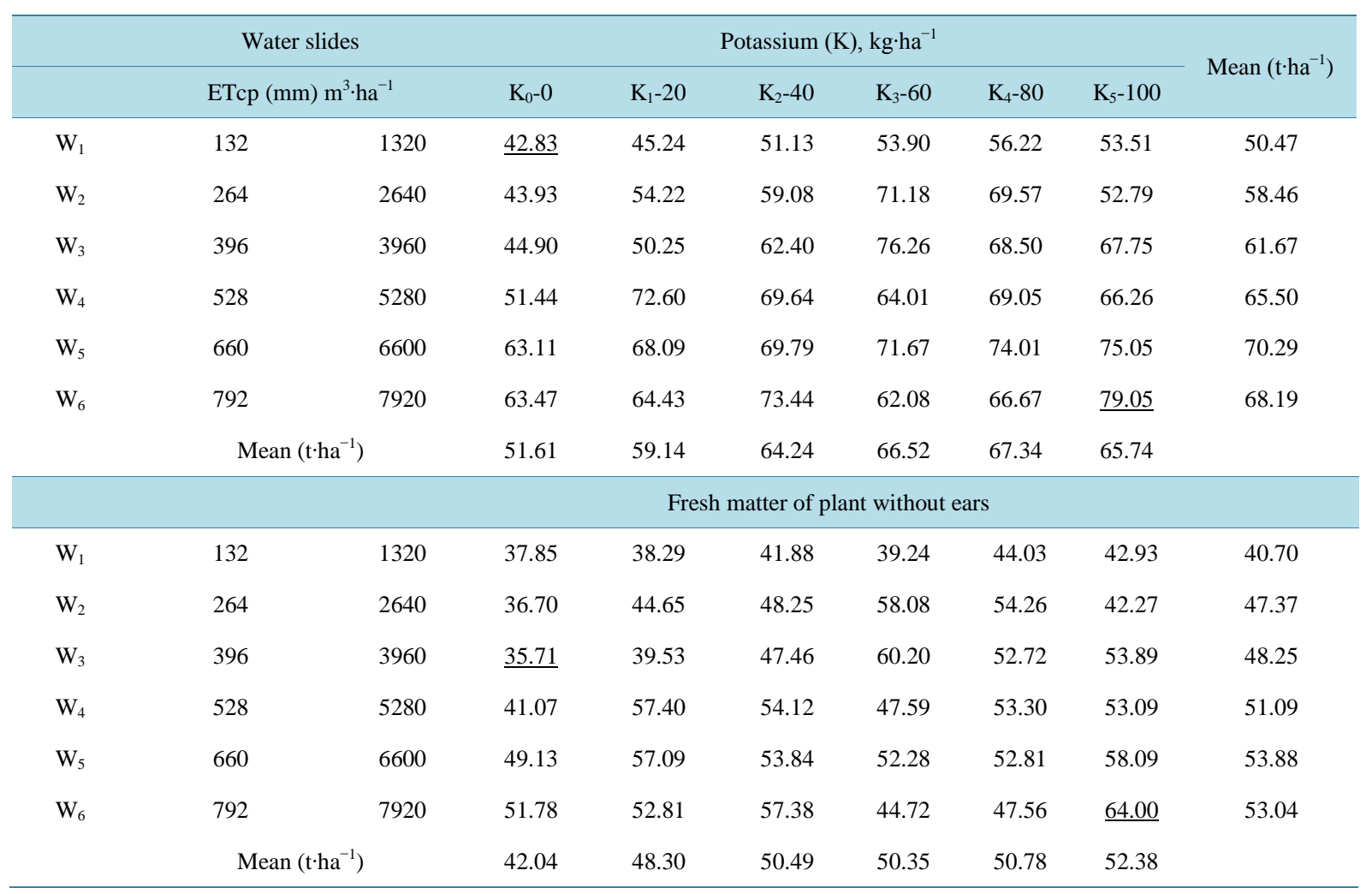

potassium, since the grain addition, the vegetative portion is also removed from the ground-depleting if no replenishment of nutrients. According [12] the increment of K doses influenced positively the yield of corn. However, [13] evaluating potassium irrigated maize, not observed increase in productivity, since the farmers are using rates of potassium fertilizers over than necessary in this experimental region. Similarly, [14] and [15] also found no significant effect on potassium on grain corn.

The amount of biomass produced by the plant can be defined by a single physiological relationship based on the amount of radiation intercepted and their conversion efficiency on dry matter [16].

The mean of FMP with ears relative water depths ranged from 50.47 to $70.29 \mathrm{t}^{\mathrm{h}} \mathrm{ha}^{-1}$ for 132 and $660 \mathrm{~mm}$ of water. Regarding fertilization with potassium FMP with ears averages ranged from 51.61 to $67.34 \mathrm{t} \cdot \mathrm{ha}^{-1}$ in $\mathrm{K}_{0}$ and $\mathrm{K}_{4}$ treatments, respectively.

Regression models that predict FMP with ears depending on water depth (W) and fertilization (K) showed good fits to the data analyzed according to the $\mathrm{R}^{2}$ values 0.97 to 0.99 of the two equations, respectively (Table 3).

Through analysis of variance was observed that the factors water depths, potassium fertilization and interaction between them, significantly influenced the level of $1 \%$, green plant mass without ears (Table 1 ).

The production of FMP without ears ranged from 35.71 to $64.00 \mathrm{t} \cdot \mathrm{ha}^{-1}$ (Table 2) where in the overall average in the experiment was $49.1 \mathrm{t} \cdot \mathrm{ha}^{-1}$, i.e., above the production of $44.98 \mathrm{t} \cdot \mathrm{ha}^{-1}$ recorded by [11] whose authors evaluating the productivity of many corn hybrids observed yields 42.31 to $47.93 \mathrm{t}^{-\mathrm{ha}^{-1}}$. Likewise, the mean 42.04 $\mathrm{t} \cdot \mathrm{ha}^{-1}$, corresponding to produce FMP without ears with several layers of water without $\mathrm{K}$ fertilization was the highest average $22.02 \mathrm{t}^{\mathrm{h}} \mathrm{ha}^{-1}$ observed by [17] evaluated when producing the same hybrid this research, i.e., AG 1051, using various water depths. However, [18], evaluating different irrigation systems in planting hybrid corn Agroceres $8011 \mathrm{Y}$, met with full irrigation, $91.7 \mathrm{t} \cdot \mathrm{ha}^{-1}$ of green mass.

By unfolding from mean FMP without ears obtained in water depths within the quantitative potassium showed that the increase in water depths up to $\mathrm{W}_{5}$ increased production of green mass, decreasing from that point, i.e., $\mathrm{W}_{5}$ to $\mathrm{W}_{6}$. 
Table 3. Regression models with the water depths and potassium fertilization to maximize the fresh matter of plant with and without ears.

\begin{tabular}{|c|c|c|c|c|c|c|c|c|c|c|}
\hline \multirow{3}{*}{$\begin{array}{c}\text { Source of variation } \\
\text { Water depths (W) }\end{array}$} & \multicolumn{10}{|c|}{ Regression models } \\
\hline & FMP with ears & $=$ & -0.00005 & $\mathrm{~W}^{2}$ & + & 0.07 & W & 42.28 & with $\mathrm{R}^{2}=$ & 0.97 \\
\hline & FMP with ears & $=$ & 66.09 & $\mathrm{t} \cdot \mathrm{ha}^{-1}$ & To & $\mathrm{W}=$ & & 690 & $\mathrm{~mm}$ & \\
\hline \multirow{2}{*}{ Potassium (K) } & FMP with ears & $=$ & -0.002 & $\mathrm{~K}^{2}$ & + & 0.419 & $\mathrm{~K}$ & 51.73 & with $\mathrm{R}^{2}=$ & 0.99 \\
\hline & FMP with ears & $=$ & 73.68 & $\mathrm{t} \cdot \mathrm{ha}^{-1}$ & To & $\mathrm{K}=$ & & 104.75 & $\mathrm{Kg} \cdot \mathrm{ha}^{-1}$ & \\
\hline \multirow{2}{*}{ Water depths (W) } & FMP without ears & $=$ & -0.00003 & $\mathrm{~W}^{2}$ & + & 0.05 & $\mathrm{~W}$ & 35.66 & with $\mathrm{R}^{2}=$ & 0.96 \\
\hline & FMP without ears & $=$ & 53.29 & $\mathrm{t} \cdot \mathrm{ha}^{-1}$ & To & $\mathrm{W}=$ & & 766.7 & $\mathrm{~mm}$ & \\
\hline \multirow{2}{*}{ Potassium (K) } & FMP without ears & $=$ & -0.002 & $\mathrm{~K}^{2}$ & + & 0.22 & $\mathrm{~K}$ & 43.03 & with $\mathrm{R}^{2}=$ & 0.89 \\
\hline & FMP without ears & $=$ & 48.74 & $t \cdot h a^{-1}$ & To & $\mathrm{K}=$ & & 52.1 & $\mathrm{Kg} \cdot \mathrm{ha}^{-1}$ & \\
\hline
\end{tabular}

When the amount of potassium was increased, the FMP without ears also increased of $14.9 \%, 4.5 \%, 0.85 \%$ and $3.15 \%$ from $\mathrm{K}_{0}$ to $\mathrm{K}_{1}, \mathrm{~K}_{1}$ to $\mathrm{K}_{2}, \mathrm{~K}_{3}$ to $\mathrm{K}_{4}$ and $\mathrm{K}_{4}$ to $\mathrm{K}_{5}$, respectively, but with a slight decrease of $0.28 \%$ from $K_{2}$ to $K_{3}$, without a plausible explanation.

The best combination for FMP without ears was $\mathrm{W}_{6} \mathrm{~K}_{5}$ averaging $64 \mathrm{t} \cdot \mathrm{ha}^{-1}$, and the lowest mean was observed in $\mathrm{W}_{3} \mathrm{~K}_{0}$ combination with $35.71 \mathrm{t} \cdot \mathrm{ha}^{-1}$ in a population of 56,000 plants per hectare.

Factors such as mineral nutrition, radiation and water availability, significantly interfere with photosynthetic mechanism which results in the accumulation of organic matter in the plant. Among these factors, the availability of water plays a significant role because, besides providing the entry of $\mathrm{CO}_{2}$, it promotes cooling the plant, interfering in this way, the rate of photosynthesis and respiration [16].

The equations of regression models that predict FMP without ears depending on the water depths $(\mathrm{W})$ and potassium fertilization (K), with $\mathrm{R}^{2}$ of 0.957 and 0.898 , respectively, showed optimal adjustments to the data analyzed (Table 3).

\section{Conclusions}

Based on the results of this research, the water depths in irrigation that maximized the physiological parameters of plants as FMP with ears and FMP without ears were, respectively, $690 \mathrm{~mm}\left(66.09 \mathrm{t}^{\mathrm{h}} \mathrm{ha}^{-1}\right)$ and $766.7 \mathrm{~mm}$ $\left(53.29 \mathrm{t}^{\mathrm{ha}} \mathrm{ha}^{-1}\right)$.

According to regression equations, the quantitative potassium to maximize physiological parameters of FMP with ears and FMP without ears was, respectively, $104.75 \mathrm{~kg} \cdot \mathrm{ha}^{-1}\left(73.68 \mathrm{t} \cdot \mathrm{ha}^{-1}\right)$ and $52.1 \mathrm{~kg} \cdot \mathrm{ha}^{-1}\left(48.74 \mathrm{t} \cdot \mathrm{ha}^{-1}\right)$.

\section{Acknowledgements}

To Coordination of Improvement of Higher Education Personnel (CAPES) for the award of the scholarship for the second author during the graduate school

\section{References}

[1] Santos, E.D.G., Paulino, M.F. and Queiroz, D.S. (2004) Evaluation of a Signalgrass (Brachiaria decumbens Stapf) Postponed Pasture. 1. Quality of Herbage during the Dry Season. Revista Brasileira de Zootecnia, 33, 203-213. http://dx.doi.org/10.1590/S1516-35982004000100024

[2] Von Pinho, R.G., Vasconcelo, R.C., Borges, I.D. and Rezende, A.V. (2006) Influence of Cutting Height of Plants in Agronomic Characteristics and Nutritive Value of Silages of Corn and Different Types of Sorghum. Revista Brasileira de Milho e Sorgo, 5, 266-279. http://dx.doi.org/10.18512/1980-6477/rbms.v5n2p266-279

[3] Ribeiro Junior, C.S., Salcedo, Y.T.G., Azevedo, R.A., Delevatti, L.M. and Machado, M. (2011) Use of Corn Silage Diets for Balancing in Dairy Cows. Enciclopédia Biosfera, 7, 1010-1018.

[4] Bergamaschi, H., Wheeler, T.R., Challinor, J.A., Comiran, F. and Heckler, B.M.M. (2007) Maize Yield and Rainfall on Different Spatial and Temporal Scales in Southern Brazil. Pesquisa Agropecuária Brasileira, 42, 603-613. http://dx.doi.org/10.1590/S0100-204X2007000500001 
[5] Werle, R., Garcia, R.A. and Rosolem, C.A. (2008) Potassium Leaching as Affected by Soil Texture and Potassium Availability. Revista Brasileira de Ciência do Solo, 32, 2297-2305. http://dx.doi.org/10.1590/S0100-06832008000600009

[6] Deparis, G.A., Lana, M.C. and Frandoloso, J.F. (2007) Row Spacing and Nitrogen and Potassium Fertilization in Covering for the Corn Culture. Acta Scientiarum Agronomy, 29, 517-525.

[7] EMBRAPA, Empresa Brasileira de Pesquisa Agropecuária (2011) Manual de métodos de análise de solo. 2nd Edition, Embrapa Solos, Rio de Janeiro.

[8] Ferreira, D.F. (2009) Estatística básica. 2nd Edition, UFLA, Lavras.

[9] Bernardo, S., Soares, A.A. and Mantovani, E.C. (2006) Manual de irrigação. Viçosa, MG.

[10] Restle, J., Neumann, M., Brandoni, I.L., Pascoal, L.L., Silva, J.H.S., Pellegrini, L.G. and Souza, A.N.M. (2002) Corn (Zea mays, L.) Cutting Height during Silage Processing for Young Beef Cattle Production. Revista Brasileira de Zootecnia, 31, 1235-1244. http://dx.doi.org/10.1590/S1516-35982002000500021

[11] Beleze, J.R.F., Zeoula, L.M., Cecato, U., Dian, P.H.M., Martins, E.N. and Falcão, A.J.S. (2003) Evaluation of Five Corn Hybrids (Zea mays, L.) at Different Maturity Stages. 2. Structural Component Concentrations and Correlations. Revista Brasileira de Zootecnia, 32, 529-537.

[12] Rodrigues, M.A.C., Buzetti, S., Teixeira Filho, M.C.M., Garcia, C.M.P. and Andreotti, M. (2014) Fertilization with Coated $\mathrm{KCl}$ in Corn in the Savannah. Revista Brasileira de Engenharia Agrícola e Ambiental, 18, 127-133. http://dx.doi.org/10.1590/S1415-43662014000200001

[13] Pavinato, P.S., Ceretta, C.A., Girotto, E. and Moreira, I.C.L. (2008) Nitrogen and Potassium in Irrigated Corn: Technical and Economic Analysis of the Fertilization. Ciência Rural, 38, 358-364. http://dx.doi.org/10.1590/S0103-84782008000200010

[14] Wendling, A., Eltz, F.L.F., Cubilla, M.M., Amado, T.J.C. and Mielniczuk, J. (2008) Recommendation of Potassium Fertilization for No-Till Wheat, Corn and Soybean in Paraguay. Revista Brasileira de Ciência do Solo, 32, 1929-1939. http://dx.doi.org/10.1590/S0100-06832008000500014

[15] Valderrama, M., Buzetti, S., Benett, C.G.S., Andreotti, M. and Teixeira Filho, M.C.M. (2011) NPK Sources and Doses on Irrigated Corn under No-Till System. Pesquisa Agropecuária Tropical, 41, 254-263.

[16] Charles-Edwards, D.A. (1982) Physiological Determinants of Crop Growth. Academic Press, London.

[17] Freitas, W.S., Oliveira, R.A., Pinto, F.A., Cecon, P.R. and Galvão, J.C.C. (2004) Effect of Swine Wastewater Application on Corn Production for Silage. Revista Brasileira de Engenharia Agrícola e Ambiental, 8, 120-125. http://dx.doi.org/10.1590/S1415-43662004000100018

[18] Martin, J.D., Carlesso, R., Aires, N.P., Gatto, J.C., Dubou, V., Fries, H.M. and Scheibler, R.B. (2012) Deficit Irrigation in Order to Increase the Productivity of Water Use in Maize Silage Production. Irriga Ed. Especial, 192-205. http://dx.doi.org/10.15809/irriga.2012v1n01p192 